\title{
Resources, Capabilities, Strategies and Competitive Advantage of Research University in Malaysia
}

\author{
Siti Asma’ Mohd Rosdi \\ Universiti Pendidikan Sultan Idris, Malaysia, sitiasma@fpe.upsi.edu.my
}

\begin{abstract}
This article identifies important elements acquired and bundled by Higher Education Institutions (HEIs) to attain competitive advantage. Competitive advantage is the crucial concept of sustainable development of Research University (RU). This article explores the competitive advantages of research university (RU) with a specific focus in the Malaysian context. The article guided by these questions - "What is competitive advantage?" and "What are competitive advantage elements for RU?" - in examining the resource, capability and strategy for RU. Using a qualitative method, interview was conducted. A qualitative thematic strategy was adopted to analyze and interpret the data. Results show that the RU has been acquiring and bundling sufficient resources and high capabilities to implement university strategies. This finding in line with the aspect of internationalization of HEIs such as managing resource, personnel and international networking, international research projects, international research outputs, student-staff mobility, and the internationality of curriculum and academic profile of institutions. Thus, this article provides a base to construct a model tailored for Malaysian Research University.
\end{abstract}

Keywords: competitive advantage, resource, capability, strategy, research university

\section{INTRODUCTION}

Globally, higher education institutions (HEIs) quest for the quality of teaching and learning, recognition of research and development, innovation excellent and contribution to society. These institutions have evolved far beyond the traditional settings where it has become a place for disseminating and producing knowledge as well as commercializing their research output which contributed largely to the country's economic development. HEIs have face competition and challenges situation in order to gain competitive advantage in both national and international setting.For example, changing government policy, ongoing student growth, stakeholder demand for quality, change in leadership, renewed institutional strategy; and financial sustainability are some of the internal factors contributing to the challenges within universities (Shah and Nair, 2016). For Malaysian HEIs, the role is changing to meet the needs of today and more critically, that of tomorrow. Thus, acknowledging the problems and challenges ofMalaysianHEIs, where criticisms have been raised about the sustainability of these institutions (Wan, Sirat and Abdul Razak, 2015).

Higher education institutions(HEIs) confronted with a big challenge in finding a balance between traditional academic operation and the new operation of international dominant market-driven competition (Cheung and Chan, 2010).In international market-driven competition, HEIs have linked with social, economic, environmental and cultural-political concerns in order to achieve sustainability (Wooltorton, Wilkinson, Horwitz, Bahn, Redmond and Dooley, 2015).According to Reinhart, (2010) sustainable practices are not just good for the environment, but also good for 
business practices, healthy living, and the community. Collis and Montgomery, (1995) proposed the idea that competitive advantage can be derived from internal skills, resources or assets is widely referred to as the resource-based view whereas Mazzarol and Soutar (1999) also proposed the competitive advantage model in international market of higher education. Therefore, resource, capability and strategy of competitive advantage is a vital factor in achieving excellence in higher education performance, embedded in a person that upholds the notions of whoever strives shall succeed (Helen de Haan, 2015).

This paper seeks to explore the elements of competitive advantage in Research University (RU) with a specific focus in the context of Malaysia. There are studies such as Helen de Haan (2015), Knight, (2004, 2011), Naidoo, (2010), Mazzarol and Soutar (2008), Marginson, (2007), Lynch and Baines, (2004)covering the concept of competitive advantage in HEIsbut little studies to be found in the literature on what the concept competitive advantage actually means for HEIs (Helen de Haan, 2015).Helen de Haan, (2015) identified 13 elements of competitive advantages sought by public higher education institutions (PHEIs) and examine differences between the perceptions of competitive advantage in different sectors which are research universities (RU) and universities of applied sciences (UA) and the different job function levels (central and faculty).However, this study identifies the dynamic elements acquired and bundled by RU to attain competitive advantage and predefined the dynamic elements of competitive advantage as financial resource, human resource, physical resource, capabilities and strategies. The main interest of this study upholds that dynamic element of competiti advantage is a significant factor of faculty success that has less discovered in HEIs. Therefore, the novelty of this study is strived to fill the gap by investigating dynamic elements of competitive advantage from successful faculty in RU that determine HEI ssuccess.

This paper consists of seven sections. First, this paper generally introduces the concept of competitive advantage in HEIs. Second, examine the competitive advantage of Malaysian HEIs. Third, explore the views of competitive advantage, guided by the question: "What are competitive advantage elements for RU?" This is followed by the section four which discuss the finding of a competitive for the Malaysia's RU specifically in resources, capabilities and strategies. The section five is discussion on the way forward. The conclusion briefly deliberates in section six and limitation and future research deliberates final section.

\section{LITERATURE REVEW}

Regularly, "competitive advantage" offer more economic value and enable the firm to earn greater economic value than their competitors. The concept of competitive advantage has a long history and tradition in the strategic management literature. According to Haijing Helen de Haan (2015), the concept of "competitive advantage" was first described by Ansoff (1965) as the "properties of individual products/markets which will give the firm a strong competitive position" (p. 79). In addition, Uyterhoeven et al. (1973) discussed on the manner of skills and resources that apply by a firm on investment in a product market to gain superior return referred to "competitive advantages". South (1981, p. 15), defined competitive advantage as the "philosophy of choosing only those competitive arenas where victories are clearly achievable." Recent literature defined "competitive advantage" as mobility barriers and/or market positions and/or idiosyncratic firm 
resources and capabilities lead to mobility barriers and/or market positions and/or idiosyncratic firm resources and capabilities which in turn lead to superior performance (Sigalas, 2015).

In an attempt to classify all definitions of competitive advantage by the most important contributors in the field of strategic management, Sigalas, Pekka-Economou and Georgopoulos (2013) have identified two streams concerning competitive advantage's conceptual demarcation. The first stream defines competitive advantage in terms of performance, e.g. high relative profitability, above average returns, benefit-cost gap, superior financial performance, economic profits, positive differential profits in excess of opportunity costs and cross-sectional differential in the spread between product market demand and marginal cost. The second stream defines competitive advantage in terms of its sources or determinants, e.g. particular properties of individual product markets, cost leadership, differentiation, locations, technologies, product features and a set of idiosyncratic firm resources and capabilities. Therefore there a link between high performance of the firm and competitive advantage (Greve, 2009). Peteraf, Stefano and Verona (2013) argue that dynamic bundle of resources and capabilities comprise more stable elements and therefore it would be an alternative source to sustain or prolong competitive advantage.

\section{Competitive advantage of Higher Education Institutions (HEIs)}

Originally, the notion of "competitive advantage" were developed in the private business sector, but are claimed to be applicable in the public sector (e.g. Powell, 2001). Powell, (2001) explores the logical and philosophical foundations of the competitive advantage hypothesis, locating its philosophical foundations in the epistemologies of Bayesian induction, abductive inference and an instrumentalist, pragmatic philosophy of science. Competitive advantage has been applied when HEIs are viewed as service providers in a marketplace (Mazzarol and Soutar, 2008). Thus, HEIs have always had the ecosystem of being competitive in trying to reach high academic standards, to achieve academic excellence, and to obtain international reputation and status (Chan and Dimmock, 2008). To achieve sustainable competitive advantage, resources and capabilities should be integrated by HEIs.

According to Larran, Herrera, Calzado and Andrades (2016), there is greater number of items related to sustainable development in HEIs such as corporate governance and environment, students, staff, society and companies. It is agreed by Ribeiro, Hoover, Burford, Buchebner and Lindenthal (2016) highlighted that many of the values and resources held by university staff and students are pro-sustainability values. They illustrated how values-based indicators can be integrated into university performance assessments, providing a novel way of thinking about sustainability assessment in universities based on the case study of BOKU University in Austria. They identify values that are meaningful for BOKU stakeholders, that is, they inspire stakeholders in their work/life at BOKU. These values were not only defined in BOKU stakeholders' own terms, but also directly contributed to broader institutional sustainability activities. The findings also include validated proto-indicators for each value cluster such as [1] Taking responsibility for the environment and protecting, preserving and respecting nature for future generations, [2] Critical thinking, [3] Finding and following one's own path within and "with" BOKU, [4] Spirit of research, science and developing solutions for existing problems in society and in practice, [5] Integral and systemic reflection, [6] Cooperation and teamwork, [7] Networking and 
(interdisciplinary) exchange of knowledge and experience, [8] Friendly, cooperative working atmosphere and social interaction.

Literatures suggested the elements of competitive advantage in HEIsfor example; Helen de Haan (2015) critically investigated the discourse on competitive advantageand gets some insightful understanding about how competitive advantage is actually manifested in the life and activities of HEIs.The elements of competitive advantage are actually overlapped with other studies (e.g Knight, 2004, 2011, Naidoo, 2010, Mazzarol and Soutar, 2008, Marginson, 2007, Lynch and Baines, 2004). Table 1.0 below is present the detail of competitive advantage's elements according to the literature.

Table 1.0: Elements of Competitive Advantage in Higher Education Institutions (HEIs)

\begin{tabular}{|c|c|c|}
\hline ELEMENT & PREDEFINED & LITERATURE REVIEW \\
\hline $\begin{array}{l}\text { RESOURCE } \\
\text { Financial } \\
\text { Resource }\end{array}$ & $\begin{array}{ll}\text { - } & \text { Generated fund through } \\
\text { grant } \\
\text { - } \\
\text { Seminar/workshop/confere } \\
\text { nce } \\
\text { - Rent school facilities }\end{array}$ & 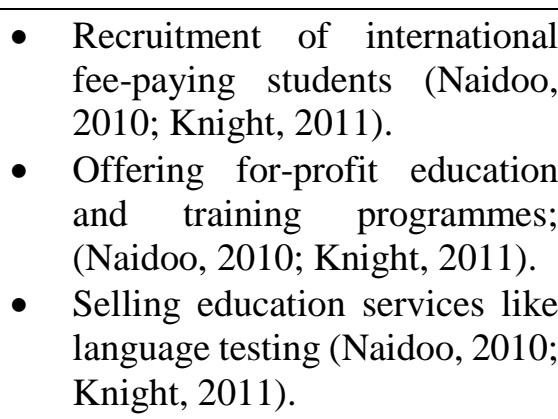 \\
\hline $\begin{array}{l}\text { Human } \\
\text { Resource }\end{array}$ & $\begin{array}{l}\text { - Staff have experienced } \\
\text { more than } 10 \text { working } \\
\text { experience } \\
\text { - } \quad \text { Capable and skilled } \\
\text { - Responsiveness and } \\
\text { flexibility }\end{array}$ & $\begin{array}{l}\text { Doing better, being the best } \\
\text { (Helen de Haan, 2015) } \\
\text { - Experiential knowledge } \\
\text { (Helen de Haan, 2015) } \\
\text { - Attracting student (Knight, } \\
\text { 2004; Marginson, 2007) }\end{array}$ \\
\hline $\begin{array}{l}\text { Physical } \\
\text { Resource }\end{array}$ & $\begin{array}{l}\text { - } \text { Spacious lecturer halls } \\
\text { - } \text { Computer system } \\
\text { - } \text { Air conditioning } \\
\text { - } \text { Conference room } \\
\text { - } \text { Tele-conferencing } \\
\text { - } \text { Library }\end{array}$ & $\begin{array}{l}\text { Quality of facilities and } \\
\text { services (Helen de Haan, 2015) } \\
\text { - Geographic location/living } \\
\text { environment (Helen de Haan, } \\
\text { 2015) }\end{array}$ \\
\hline CAPABILITY & $\begin{array}{l}\text { - Qualified lecturer and } \\
\text { academic staff } \\
\text { - Taking values into concern } \\
\text { - Multi-culture tasking }\end{array}$ & $\begin{array}{l}\text { Quality of education and/or } \\
\text { research (Knight, 2004; } \\
\text { Marginson, 2007; Helen de } \\
\text { Haan, 2015) }\end{array}$ \\
\hline STRATEGY & $\begin{array}{ll}\text { - } & \text { Networking } \\
\text { - } & \text { Collaborate with other } \\
\text { universities } \\
\text { - } \quad \text { Events and conference } \\
\text { - } \text { Maintaining the pensioned } \\
\text { professors or lecturer }\end{array}$ & $\begin{array}{l}\text { Reputation/brand/image/attracti } \\
\text { veness (Helen de Haan, 2015) } \\
\text { - Unique selling point, being } \\
\text { different (Helen de Haan, } \\
\text { 2015) }\end{array}$ \\
\hline
\end{tabular}




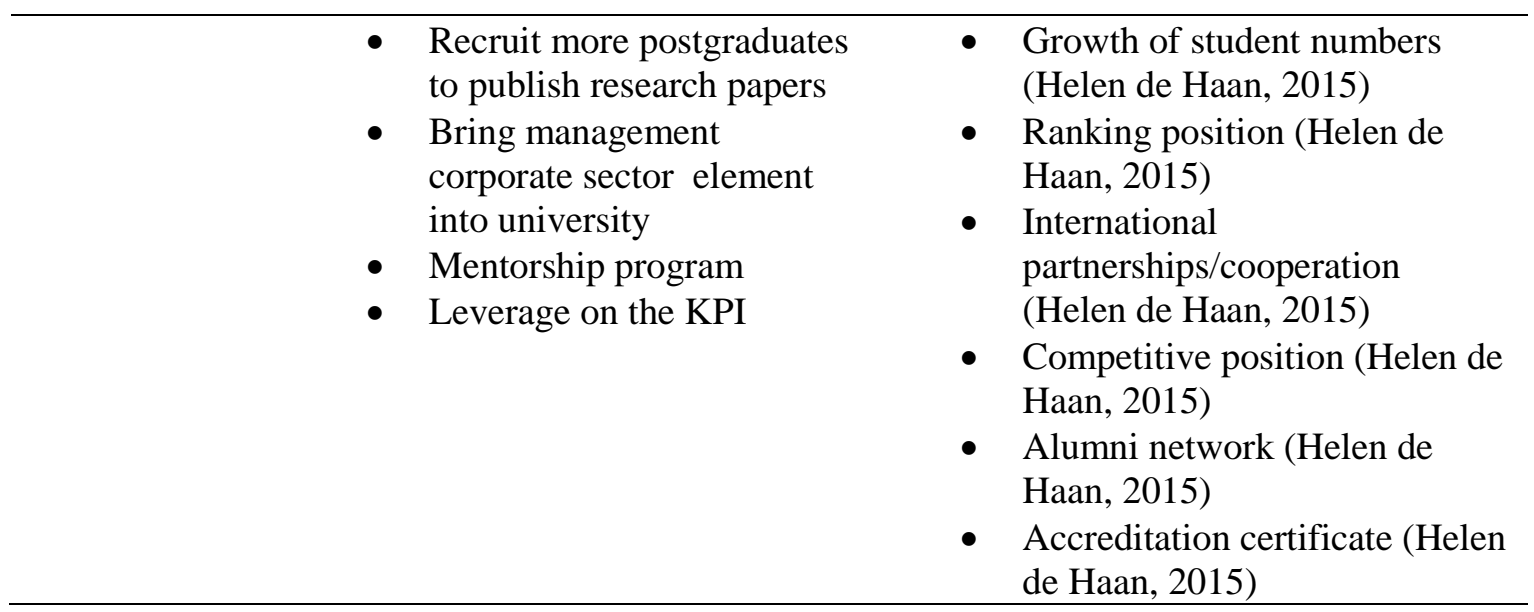

\section{Resources}

In HEIs, there are several resources related to higher education namely tangible (financial, human and physical) and intangible (knowledge, expertise and experience). Tangible and intangible resource enable lecturer to lead the students towards achievement and improvement in academic aspect as well as self-development aspect such as analytical skill, critical thinking and creativity. Liefner (2003) analyzes the forms of resource allocation in university systems and their effects on performance in HEIs. Internationally, higher education systems differ substantially with regard to research and education funding sources and to ways that resources are allocated. For example, many governments use competitive elements in the process of allocating public funds to HEIs. Examples include the implementation of performance measures through "formula funds", or resource allocation on the basis of evaluated project proposals (Liefner, 2003). Corresponding forms of performance-based resource allocation can be found within most HEIs. The competence of resources is fundamental for the resources that are used to develop the capacity.

According to Dawson, Burnett, and O'Donohue (2006), HEIs promoting the integration of physical resource such as communication resource (e.g. discussion forums and chat) to supplement traditional modes of teaching and learning and for the development of online delivery to distributed education students, the communication resources are likely to be integrated with current learning activities to aid in the facilitation of peer-to-peer interactions. However, the dynamic capabilities concept as an extended approach of the traditional resource-based view of strategic management is a well-researched area to deal with rapid changes in competitive market forces; the concept has limitations and criticisms (Riad Shams, 2016). Resources are the organizational capital, physical, and human inputs through the process. A set of resources becomes a "capability" when they are united or integrated into core competencies to have a competitive advantage.

\section{Capabilities}

Understanding the capabilities of HEIs is vital togenerate strategically valuable innovation and sustainable competitive advantage. According to Stephenson (1998) capabilities is an integration of knowledge, skills, personal qualities and understanding used appropriately and effectively-not just in familiar and highly focused specialist contexts but in response to new and changing 
circumstance. Personal capability includes self-regulation, which refers to deferring judgement and not jumping in too quickly to resolve a problem, understand one's personal strengths and limitation, admitting and learning from error, maintaining work life balance and able to handle pressure under unexpected circumstances. The personal capability in HEIs is referring to the head of department or faculty to manage and as a decision maker of the department. Head of department should be able in handling the quality of teaching and learning, recognition of research and development, innovation excellent, contribution to society, effective management, and networking with important stakeholders. For example, Bobe and Kober (2015) measure the organizational capabilities of university departments and argues that heads of departments conceive of the development of capabilities within their departments along the functional dimensions of research, teaching and networking appears logical given these are the core functions of universities, and that departments are responsible for the operational delivery of these functions.

On the other hands, effective capabilities of governance in HEIs inspiring leadership to have effective education system for sustainable competitive advantage, while efficient leadership with a clear focus on sustainability affects the HEIs as a sustainable practitioner. For example, Littledyke, Manolas and Littledyke, (2013) investigate HEIs system for sustainability practice and argued that effective education for sustainability in HEIs requires clear vision for leadership and support based on agreed purposes and sustainability practices through coordinated governance, curriculum and infrastructure management. Therefore, capabilities would be a dynamic source to sustain or prolong competitive advantage.

\section{Strategies}

The strategies of HEIs are much closed with particular vision and mission of each department/faculty/administrative unit. According to Porter (1990), there are three strategies that have been proposed which can be used singly or in combination to create competitive advantage in the long run of HEIs; those strategies are leadership, differentiation and focus. Furthermore, Kettunen (2002) describes the generic strategies presented by Porter (1990) and explores how heads of departments can use them to define the strategies of departments to shape the future direction. The HEIs which define their strategy predominantly in terms of senior management responsibilities at the top level of the organization are unlikely to be making the besto utcomes. It is important to encourage heads of departments and their staff to participate in their own strategy process in order to find out their competitive strategy, which is in line with the strategy of the institution as a whole. Effectively implementing any of these strategies requires total commitment to cope with competitive market pressures has therefore gained primacy for HEIs.

Naidoo (2010) stated that in order to enhancing competitive advantages of HEIs, students' engagement in a learning community increasingly make up a great part of growth strategy at many HEIs, and this also implies the use of new tools such as internationalisation, marketing and promotion. Shah and Nair (2016) argue the need for the renewed emphasis on strategy development and effective implementation in HEIs and stated that there are trend and benchmarked performance data at university/faculty/administrative unit of study level provides diagnostic analysis on the performance at each of these levels which then enables quality decision making. Certain HEI has adopted a very specific strategy in its quest for a sustainable future. For example, Barnard and Van der Merwe, (2016) indicated that the University of Johannesburg (UJ) 
offers a wide range of academic programs (from short courses, certificates, diplomas, junior degrees and postgraduate degrees) strategically position itself as a global establishment of relevant, quality research and higher education.

\section{METHODOLOGY}

This research targeted one of RU in Malaysia due to the recognition of world class status. The interviews were carried out with different experienced lecturers in the school/faculty. I approached lecturers who are holding administration position to seek for their on-post experiences, research interests in education and human resource. The interviews were conducted in English. All interviews were recorded and transcribed verbatim in English by a professional transcriptionist. The interview questions are "what is a competitive advantage?" and "what are competitive advantage elements for RU?" A qualitative thematic strategy was used to analyze and make sense of the data (Boyatzis, 1998). I first coded the data with respect to different formats (interviews, documents), then used constant comparative method to identify major themes (Glaser and Strauss, 1967). Through constant comparison, I identified subthemes under each major theme as properties or descriptors to reveal the underlying nature of the themes. The data were presented thematically and the relationship between the findings and current literature was integrated into the discussion of themes (Glaser and Strauss, 1967).

\section{FINDINGS}

The results of the interviews are presented in table 2.0 below guided by two research questions, [1] what is a competitive advantage? [2] what are competitive advantage elements for RU?. These questions have been answered based on three themes namely resources, capability and strategy.

Table 2: Findings of the interview

\begin{tabular}{ll}
\hline Themes & Findings \\
\hline Resources & First theme is considering the resource; resource is dividing into two types \\
namely tangible resource and intangible resource. Tangible resource is \\
including financial resource, human resource and physical resource. \\
However, intangible resource is specification on knowledge, experience \\
and expertise. The competitive advantage in terms of resource, I found that: \\
"The department has financial resource by finding grants locally and \\
internationally. The department is able to generate fund through grants \\
based on the amount of papers lecturer published. Organized seminars and \\
workshop, and also offer short term courses. Besides that, the faculty rent \\
the out the faculty facilities such as conference room, lecture hall to \\
generate more income. In terms of human resource, faculty has academic \\
staff with experienced more than 10 years and 80\% of the university's \\
academic staffs are PhD holders. The physical resource in the university \\
and the faculty are considered the best compared to other public
\end{tabular}


universities in Malaysia. With all the quality facilities the faculty provided, students and staffs in the faculty working in the conducive environment".

Capabilities

Strategies
Second theme is capabilities with specific on the competitive advantage of capable to be the best university for sustainable development, capable to produce high quality of students, research and development, high quality of teaching and learning, and contribution to the society.The competitive advantage in terms of capabilities, I found that:

"The faculty has qualified lecturer and academic staffs, hard work. The graduate students from this faculty are always ready ever ready to practice multidisciplinary and taking values into concern; social scientists are very important to the society be competence in our future career, administrative staffs are able to increase efficiency and effective in routine work and solving problem during work, able to compete with people all around the world".

The third theme is strategy which focuses on the specific plan or policy designed to achieve the aim and objective. The competitive advantage in terms of strategy, I found that:

'The strategy is to bring management corporate sector elements into university. Moreover, maintaining the pensioned professors or lecturer; recruit more post graduates to publish research papers; capable leader and good management team; multi-tasking culture -mentorship program; leverage on the KPI-the higher the impact of the work, the more we are well known, and this can contribute a lot to the KPI and The Dean is supportive. Student and staff of the school encouraged to be proactive in learning and working, more incentive given by school to academic staff, improve working environment brings positive outcomes to the academic and administrative staff"

\section{DISCUSSION}

This paper aims to clarify the concept of competitive advantage with this question - What is a competitive advantage? and - What are competitive advantage elements for RU?, in examining the resource, capability and strategy for RU. Thus the concept of competitive advantage was viewed from resource element with determine the tangible and intangible resources. The competitive advantage also been viewed by capabilities of RU for sustainable competitive advantage where RU able to have quality of teaching and learning, recognition of research and development, innovation excellent, contribution to society, effective management, and networking with important stakeholders. Moreover the importance of competitive advantage have been examine in term of strategies that practiced by RU.

Competitive advantage has managerial implication for Malaysian HEIs especially for RU. By practicing competitive advantage in HEIs system, such that has been demonstrated by internationalization, inevitably introduces various effects to the system. Higher education in 
Malaysia has been shift to internationalization and Malaysia has since established itself as a "student hub" (Knight and Morshidi, 2011). Competitive advantage is the strategy for Malaysian HEIs to compete internationally. The element of resources, capabilities and strategies can use to manage and organized internationalisation activities at Malaysian HEIs, would serve to assure the mechanism quality in attracting and retaining international students in the country. Table 3.0 shows the discussion of the findings.

\section{Table 3: Discussion of the Findings}

\begin{tabular}{ll}
\hline Resources & $\begin{array}{l}\text { The financial resources generated by various activities, the faculty will be able to use } \\
\text { money to fund research paper, publication, allow lecturers to attend conferences and } \\
\text { most importantly to make sure the operation of the faculty runs smoothly. }\end{array}$ \\
\hline Capabilities & $\begin{array}{l}\text { Excellent management team with critical thinking, high personal, interpersonal and } \\
\text { cognitive capabilities that bring in corporate elements will ensure the operation of the } \\
\text { faculty actively and effectively in the long run. }\end{array}$ \\
Quality of publication should be revised in order to gain citation and popularity in the \\
world. Everyone in the university plays an important role in achieving a higher ranking \\
in the world, regardless by faculty or university. With sufficient resource, high \\
capabilities, achievable strategies and competitive advantages, can be sustain and \\
accelerate the performance of the university in order to achieve a higher ranking in the \\
world.
\end{tabular}

This finding was supported byKnight(2004); Marginson, (2007); and Helen de Haan (2015) by identified the elements of competitive advantage such as quality of education, research, facilities and service (resource); reputation and attractiveness (capabilities) as well as ranking position and being different (strategies). This result also corroborated with Shah and Nair (2016), found that strategy development provides confidence to staff, students and other stakeholders that the university and the senior management team are aware of the challenges and the strategy is aimed to build on the current strengths and take advantage of the current and predicted landscape. Moreover, our finding is similar to Naidoo, (2010) and Knight, (2011) who agreed that recruitment of international fee-paying students, offering for-profit education and training programs and selling education services like language testing is the strategies to ensure trust between the university leaders and its stakeholders.

\section{CONCLUSION}

There is no doubt that RU now operate in a turbulent environment with constant change due to social, political and economic changes within the external and internal operating environments. These changes require renewed emphasis on strategy development, implementation and accountability at all levels to operationalize and monitor the effectiveness of the strategy. The literature strongly suggests that many scholars recognise the need for strategy development at a time of uncertainty. HEIs can use resource, capability and strategy of competitiveness in order to predict performance. Resource, capability and strategy of a RUplays an influential role in higher education capability to achieve faculty's competitive advantage, respond to environments, create value and growth and contribute to economic and social wellbeing of the society. Therefore, 
competitive advantage represents a crucial component of economic growth and a main contributing factor to a nation's prosperity where faculty leader or dean represents a catalyst of a source of competitive advantage; exploits opportunities in his environment and utilizes resources effectively to maximize profits and minimize costs. HEIs is synonymous with the growth of civilization, with the single most important medium for conserving, understanding, extending and passing on the intellectual, scientific, and artistic heritage from one generation to the next in society (Collini, 2012). This, in turn, would hopefully strengthen the efforts of academics to reach a consensus regarding the conceptual nature of competitive advantage.

\section{LIMITATIONS AND FUTURE RESEARCH}

These findings are subject to the usual limitations arising from the field survey method. The interview used in this study has not been triangulated with data from other sources. At the micro level of resource management, the findings give rise to several questions for practice. Within a bundle of resources underlying a functional capability, which particular resources are more critical to achieving sustained competitive advantage in that capability? Can a separate bundle of resources be managed to improve a particular capability (e.g. teaching) without causing an impact on another capability (e.g. research)? What effects do changes in government regulations or recalibrations of university strategic priorities have on the management of bundles of resources and the rate at which capabilities can be reoriented at the school/department level? Further research could address such questions, and provide greater insights into the issue of managing resources in the university sectorfor the development of capabilities that provide sustained competitive advantage. Future research could also seek to refine the instrument constructed in this study and further test its validity.

\section{REFERENCES}

Ansoff, I. (1965). Corporate Strategy. McGraw-Hill: New York, NY.

Barnard, Z. and Van der Merwe, D. (2016).),"Innovative management for organizational sustainability in higher education", International Journal of Sustainability in Higher Education, Vol. 17 Iss 2 pp. 208 227.

Bobe, B.J, and Kober, R. (2015). Measuring organisational capabilities in the higher education sector. Education + Training, Vol. 57 Iss 3 pp. $322-342$.

Boyatzis, R. (1998). Transforming qualitative information: thematic analysis and code development. Sage: Thousand Oaks, CA.

Chan, W.W.Y. and Dimmock, C., (2008). The internationalisation of universities: globalist, internationalist and translocalist model, Journal of Research in International Education, Vol. 7 No. 2, pp. 184-204.

Cheung, H.Y. and Chan, A.W.H. (2010). Education and competitive economy: how do cultural dimensions fit in? Higher Education, Vol. 59 No. 5, pp. 525-541.

Collini, S. (2012). What Are Universities For? London: Penguin.

Collis, D.J. and Montgomery, C.A. (1995). Competing on resources: strategy in the 1990s. Harvard Business Review, Vol. 73 No. 4, July-August, pp. 118-28.

Dawson, S., Burnett, B., and O' Donohue, M. (2006). Learning communities: an untapped sustainable competitive advantage for higher education. International Journal of Educational Management, Vol. 20 Issue: 2, pp.127-139.

Glaser, B. and Strauss, A. (1967). The discovery of grounded theory: strategies for qualitative research. Aldine: Chicago, IL. 
Greve, H.R. (2009). Bigger and safer: the diffusion of competitive advantage. Strategic Management Journal. Vol. 30 No. 1, pp. 1-23.

Helen de Haan, H. (2015). Competitive advantage, what does it really mean in the context of public higher education institutions?. International Journal of Educational Management, Vol. 29 Iss1,pp. 44 - 61.

Kettunen, J. (2002). Competitive strategies in higher education. .Journal of Institutional Research. Vol. 11, No. 2, pp. 38-47.

Knight, J. (2004). Internationalization remodeled: definition, approaches, and rationales. Journal of Studies in International Education, Vol. 8 No. 1, pp. 5-31.

Knight, J. (2011). Education hubs: a fad, a brand, an innovation?. Journal of Studies in International Education, Vol. 15 No. 3, pp. 221-240.

Knight, J. and Morshidi Sirat. (2011). The complexities and challenges of regional education hubs: Focus on Malaysia. Higher Education, 61(5), 593-606.

Larran, M., Herrera, J., Calzado, Y., and Andrades, J. (2016). A proposal for measuring sustainability in universities: a case study of Spain. International Journal of Sustainability in Higher Education, Vol. 17 Iss 5.

Liefner, L. (2003). Funding, resource allocation, and performance in higher education systems. Volume 46 Issue 4, pp 469-489.

Littledyke, M., Manolas, E and Littledyke, R.A. (2013). A systems approach to education for sustainability in higher education. International Journal of Sustainability in Higher Education, Vol. 14 Iss 4 pp. 367 $-383$.

Lynch, R. and Baines, P. (2004). Strategy development in UK higher education: towards resource-based competitive advantages. Journal of Higher Education Policy and Management, Vol. 26 No. 2, pp. 171187.

Marginson, S. (2007). University mission and identity for a post post-public era. Higher Education Research \& Development, Vol. 26 No. 1, pp. 117-131.

Mazzarol, T., and Soutar, G.N. (1999). Sustainable competitive advantage for educational institutions: a suggested model. International Journal of Educational Management, Vol. 13 Iss 6, pp. 287 - 300.

Mazzarol, T. and Soutar, G.N. (2008). Strategy matters: strategic positioning and performance in the education service sector. International Journal of Nonprofit and Voluntary Sector Marketing, Vol. 13 No. 2, pp. 141-151.

Naidoo, V. (2010). From ivory towers to international business are universities export ready in their recruitment of international students? Journal of Studies in International Education, Vol. 14 No. 1, pp. $5-28$.

Peteraf, M., Stefano, G.D. and Verona, G. (2013). The elephant in the room of dynamic capabilities: bringing two diverging conversations together. Strategic Management Journal, Vol. 34 No. 2, pp. 1389-1410.

Porter, M.E. (1990). The Competitive Advantage of Nations. London: Macmillan.

Powell, T.C. (2001). Competitive advantage: logical and philosophical considerations. Strategic Management Journal, Vol. 22 No. 9, pp. 875-888.

Reinhart, L. (2010). Giving back to your community through sustainability. Facility Manager, Vol. 26 No. 2, p. 59.

Riad Shams, S.M. (2016). Capacity building for sustained competitive advantage: a conceptual framework. Marketing Intelligence \& Planning, Vol. 34 Iss 5, pp. $671-691$.

Ribeiro, M.M., Hoover, E., Burford, G., Buchebner, J., and Lindenthal., T. (2016). Values as a bridge between sustainability and institutional assessment. International Journal of Sustainability in Higher Education, Vol. 17 Iss 1, pp. 40 - 53.

Shah, M., and Nair, C., S. (2016). Turning the ship around. Quality Assurance in Education, Vol. 22 Issue 2, pp. $145-157$.

South, S.E. (1981). Competitive advantage: the cornerstone of strategic thinking. Journal of Business Strategy, Vol. 1 No. 4, pp. 15-25.

Stephenson, J., M. (1998). Capability and quality of education. London: Kogan Page Limited. 
Sigalas, C. (2015). Competitive advantage: the known unknown concept. Management Decision, Vol. 53 Iss 9, pp. $2004-2016$.

Sigalas, C., Pekka-Economou, V. and Georgopoulos, N.B. (2013). Developing a measure of competitive advantage. Journal of Strategy and Management, Vol. 6 No. 4, pp. 320-342.

Uyterhoeven, H., Ackerman, R. and Rosenblum, J.W. (1973). Strategy and Organisation, Irwin, Homewood, IL.

Wan, C.D., Sirat, M., and Abdul Razak, D. (2015). The Idea of a University: Rethinking the Malaysian Context. Humanities 2015, 4, 266-282; doi:10.3390/h4030266.

Wooltorton, S., Wilkinson, A., Horwitz P., Bahn, S., Redmond, J and Dooley, J. (2015). Sustainability and action research in universities. International Journal of Sustainability in Higher Education, Vol. 16 Iss 4, pp. $424-439$. 